\title{
Correlation of Lead and Zinc Contents in Sediments and Faumus Ater Against Faumus Ater Density in Reuleung River, Leupung, Aceh Besar
}

\author{
Rahmi Agustina
}

Doctoral Program of Mathematics and Science, Application of Post Graduate Program, Syiah Kuala University, Banda Aceh, Aceh, Indonesia Faculty of Teacher Training and Education, Department of Biology, Jabal Ghafur University, Sigli, Aceh, Indonesia

\begin{abstract}
Purpose - The purpose of this research is to investigate the relationship of lead $(\mathrm{Pb})$ and zinc $(\mathrm{Zn})$ contents in sediment of Faunus ater ( $F$. ater) population density and to analyze the relationship between $\mathrm{Pb}$ and $\mathrm{Zn}$ accumulation in F. ater with F. ater density in Reuleng River, Leupung, Aceh Besar.

Design/Methodology/Approach - Sampling was conducted in November 2016 until January 2017. Density of $F$. ater was analyzed by density formula while its relationship to $\mathrm{Pb}$ and $\mathrm{Zn}$ in sediments and F. ater was conducted by correlation analysis method.

Findings - The results showed that correlation between $\mathrm{Pb}$ and $\mathrm{Zn}$ in sediments and in $F$. ater varies at each locations on every month of sampling. $\mathrm{Pb}$ and $\mathrm{Zn}$ content in sediments found a fluctuating relationship in each month of sampling with density of $F$. ater. Correlation of $\mathrm{Pb}$ content in sediments with $F$. ater density showed a medium correlation in January 2017 with $r$-value $=0.665 . \mathrm{Zn}$ in sediment has a very strong

correlation to $F$. ater density in November 2016 with $r$-value $=0.891$. $\mathrm{Pb}$ in $F$. ater has a medium correlation to
\end{abstract}

(C) Rahmi Agustina, M. Ali S, Ferdinan Yulianda, Suhendrayatna. Published in the Emerald Reach Proceedings Series. Published by Emerald Publishing Limited. This article is published under the Creative Commons Attribution (CC BY 4.0) licence. Anyone may reproduce, distribute, translate and create derivative works of this article (for both commercial and non-commercial purposes), subject to full attribution to the original publication and authors. The full terms of this licence may be seen at http://creativecommons.org/licences/by/4.0/legalcode

Correlation of Lead and Zinc Contents in Sediments and Faunus Ater

\section{Ali S} \\ Faculty of Teacher Training and Education, Department of Biology, Syiah Kuala \\ University, Banda Aceh, Aceh, Indonesia \\ Ferdinan Yulianda \\ Faculty of Fisheries and Marine Sciences, Department of Water Resources \\ Management, Bogor Agricultural University, Bogor, West Java, Indonesia \\ Suhendrayatna \\ Faculty of Engineering, Department of Chemical Engineering, Syiah Kuala \\ University, Banda Aceh, Aceh, Indonesia
}


Proceedings of MICoMS 2017

\section{8}

F. ater density in January 2017 with $r$-value $=0.436$. Furthermore, accumulation of $Z n$ in $F$. ater to its density does show some apparent correlation in each month of sampling.

Research Limitation/Implications - This research gives information about the relationship of $\mathrm{Pb}$ and $\mathrm{Zn}$ contents in sediment to density of $F$. ater and to analyze correlation of $\mathrm{Pb}$ and $\mathrm{Zn}$ in $F$. ater to density of F. ater in Reuleng River, Leupung, Aceh Besar district.

Originality/Value - This is the first time research is conducted about on the correlation between lead and zinc to obtain the density of $F$. ater.

Keywords Heavy metal, lead and zinc, Faunus ater

All papers within this proceedings volume have been peer reviewed by the scientific committee of the Malikussaleh International Conference on Multidisciplinary Studies (MICoMS 2017).

\section{Introduction}

The Reuleung river lies in Leupung, Aceh Besar that crossed several villages in the area of Leupung. Land use around this river are for agriculture and human settlements, while the water is utilized for irrigation, fishery, and car washing. The Reuleng river is very meaningful to the people along watershed area; they are very much dependent on this river to meet their daily needs for water supply and agricultural irrigation. The Reuleung river is also rich with many biota, such as freshwater fish, shellfish, snails, and a number of other macrozobentos.

Faunus ater is a black snail found in this river (Figure 1). People use these snails as an additional food and sources of their income, sold in many traditional market because it can be consumed and contains high level of protein. F. ater is a mollusc of antrophoda phylum. They play significant roles in the public and veterinary health and thus need to be
Figure 1.

Faunus ater

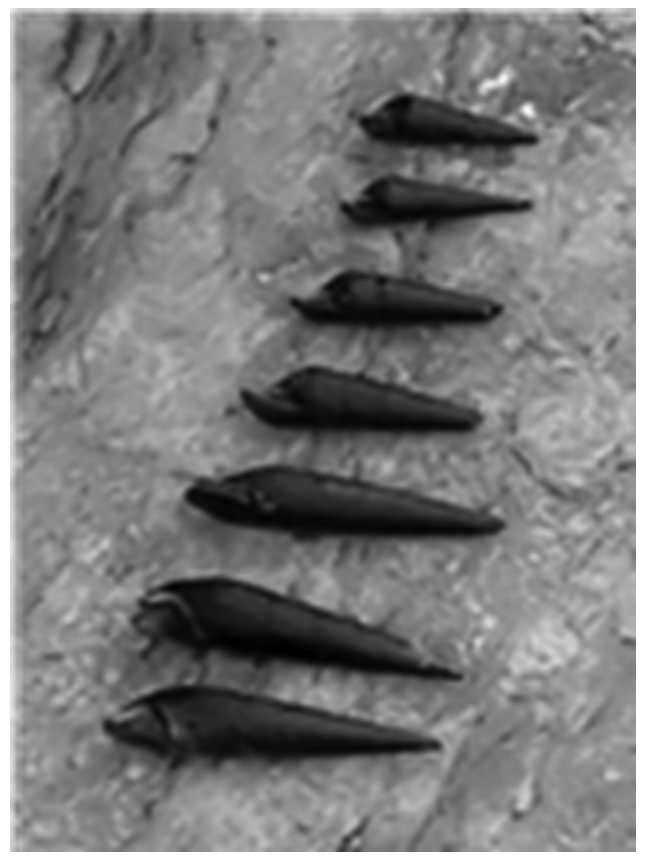


scientifically explored more extensively (Supian and Ikhwanuddin, 2002; Abd El-Wakeil et al., 2013).

Heavy metals in certain concentrations will become dangerous pollutants when entering the water (Suhendrayatna and Gultom, 2011). Heavy metals even affect the function of enzymes and fertility of aquatic species, such as organotin compounds. $\mathrm{Pb}$ will affect aquatic biota even at low concentrations (Svavarsson et al., 2001). Heavy metals will settle into sediment, so that the heavy metal content in sediment is greater than in water.

Correlation of Lead and Zinc

Contents in Sediments and Faunus Ater

\section{Materials and Methods}

Sample of sediment and $F$. ater were taken from the Reuleung river. Samples were taken from November 2016 to January 2017. The sampling sites were divided into three stations: Station 1 at the upper river; Station 2 at the watershed; and Station 3 at the mouth of the river (Figure 2). Each station was divided into three plots of sampling measuring $1 \mathrm{~m}^{2}$ each. Sample of sediment and $F$. ater were taken directly from the bottom of river, then placed into a sample bottle that has been labeled according to the station of observation, and transported to laboratory for analysis.

$\mathrm{Pb}$ and $\mathrm{Zn}$ in $F$. ater and sediments were examined using atomic absorption spectrophotometer, Shimadzu AA 630 (APHA, 2005) after constructed with toxicity characteristic leaching procedure (US-EPA, 1989). The measurement data from each station were collected in the form of tables and graphs, and discussed descriptively. Hypotheses were analyzed using the Statistical Package for Social Science (SPSS) program. Individual density level was analyzed using the following formula (Brower et al., 1989):

$$
D=\frac{N i}{A}
$$

where $D$ is the number of individuals per unit area (individual $/ \mathrm{m}^{2}$ ), $N i$ the number of individuals in quadratic transect, and $A$ the area of square transect $\left(\mathrm{m}^{2}\right)$. Correlations of $\mathrm{Pb}$

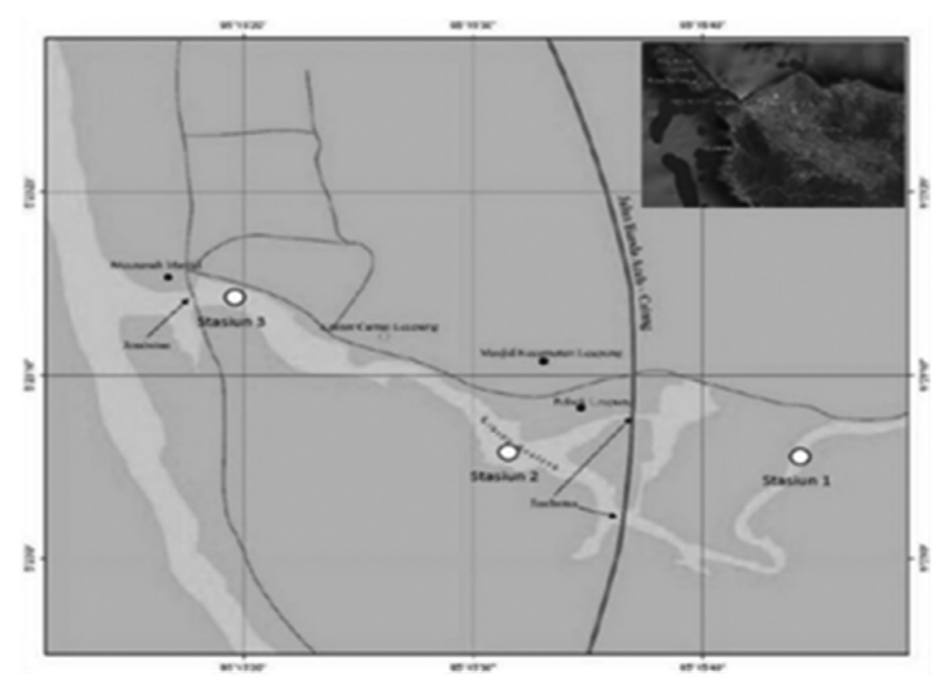

Figure 2. Location of Research 
Proceedings of MICoMS 2017

\section{0}

and $\mathrm{Zn}$ in $F$. ater and sediment to $F$. ater density were analyzed by using correlation analysis (Steel, 1989), while its data processing was supported by SPSS 14.0 program. The correlation coefficient was calculated by using the following formula:

$$
r_{X Y}=\frac{\sum x y}{\sqrt{\left(\sum x^{2} y^{2}\right)}}
$$

where $r$ is the average coefficient of correlation, $\sum x y$ the distribution of observed values $x$ and $y$, and $\sum x^{2}$ the diversity of values.

\section{Results and discussion}

\section{1. $\mathrm{Pb}$ and $\mathrm{Zn}$ Contents in the reuleung river}

During three months of observation, $\mathrm{Pb}$ and $\mathrm{Zn}$ in the sediments were found to be $0-60.732$ $\mathrm{mg}-\mathrm{Pb} / \mathrm{kg}$ and 53.61-205.3 mg-Zn/kg respectively (Table 1 ). $\mathrm{Pb}$ and $\mathrm{Zn}$ in $F$. ater were found to be $0-9.651 \mathrm{mg}-\mathrm{Pb} / \mathrm{kg}$ and $16.428-147.90 \mathrm{mg}-\mathrm{Zn} / \mathrm{kg}$ respectively. $\mathrm{Pb}$ in the sediments and $F$. ater in November and December sampling indicates that the metal content of both the sediments and the $F$. ater was too small. Analysis in January showed a very significant increase, wherein $\mathrm{Pb}$ in sediment was found to be $60.732 \mathrm{mg}-\mathrm{Pb} / \mathrm{kg}$ (Station 1), $51.096 \mathrm{mg}$ $\mathrm{Pb} / \mathrm{kg}$ (Station 2), and $60.097 \mathrm{mg}-\mathrm{Pb} / \mathrm{kg}$ (Station 3) (Table 1).

This difference happened in the research areas because of the ecological conditions in November and December marked by occurrence of several extreme storms resulting in unstable water currents. This condition affects the accumulation of $\mathrm{Pb}$ and $\mathrm{Zn}$ in sediments and $F$. ater, in contrast to $\mathrm{Zn}$, which is found both in sediments and $F$. ater at each observation station. In the first sampling on November and the second on December 2016, $\mathrm{Pb}$ content was found to be very low. This condition can occur due to weather and conditions of the river such as velocity of water currents and strong winds. The observation result at the time of sampling hold (in November and December) reported that weather condition was in extreme status.

\subsection{Density level of F. ater}

F. ater density in the Reuleng river varies in each station. Figure 3 shows that the density level at each station fluctuates every month. The highest density of $F$. ater was found at Station 3 and the lowest was in Station 2. This is because Station 3 is a rocky area which a

\section{Table 1.} $\mathrm{Pb}$ and $\mathrm{Zn}$ in sediment and $F$. ater at the Reuleng River

\begin{tabular}{|c|c|c|c|c|c|c|c|}
\hline \multirow[b]{2}{*}{ Observation Station } & \multirow[b]{2}{*}{ Sample } & \multicolumn{6}{|c|}{$\begin{array}{l}\mathrm{Pb} \text { and } \mathrm{Zn}(\mathrm{mg} / \mathrm{kg}) \\
\text { December }\end{array}$} \\
\hline & & $\mathrm{Pb}$ & $\mathrm{Zn}$ & $\mathrm{Pb}$ & $\mathrm{Zn}$ & $\mathrm{Pb}$ & $\mathrm{Zn}$ \\
\hline \multirow[t]{2}{*}{ Station 1} & Sediment & nt & 53.61 & nt & 205.30 & 60.732 & 169.082 \\
\hline & F.ater & nt & 147.90 & nt & 111.71 & 6.049 & 28.169 \\
\hline \multirow[t]{2}{*}{ Station 2} & Sediment & nt & 71.90 & nt & 103.60 & 51.096 & 89.184 \\
\hline & F.ater & nt & 82.71 & $\mathrm{nt}$ & 28.59 & 8.926 & 36.074 \\
\hline \multirow[t]{2}{*}{ Station 3} & Sediment & nt & 103.75 & nt & 137.14 & 60.097 & 90.741 \\
\hline & F.ater & nt & 66.81 & nt & 52.82 & 9.651 & 16.429 \\
\hline
\end{tabular}

Note: nt, not detected. 


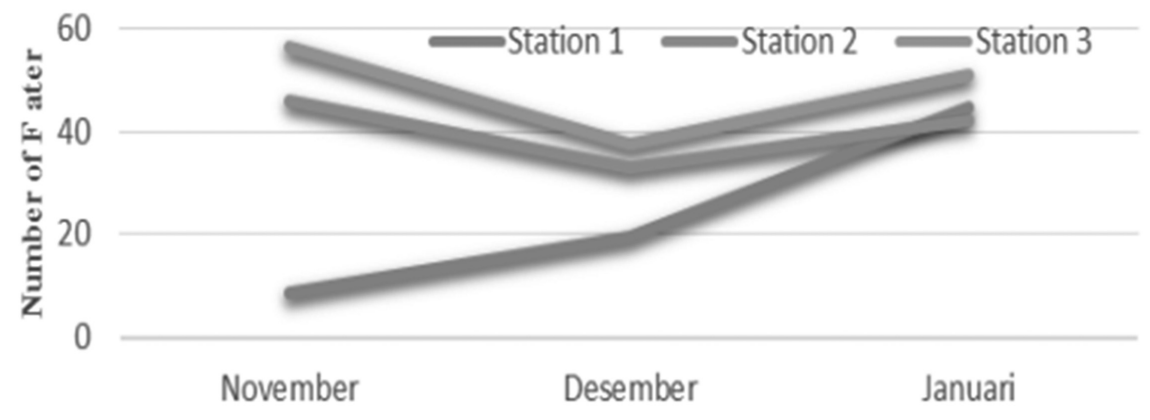

Correlation of Lead and Zinc

Contents in

Sediments and Faunus Ater

491

Time of Observations

Figure 3.

Density of F. ater

favorite habitat. This snail attached to the rocks because of many bentos on it, which is one of the food sources. So the density of $F$. ater in Station 3 was higher than in Stations 1 and 2.

\subsection{Correlation between $\mathrm{Pb}$ and $\mathrm{Zn}$ in sediments with $\mathrm{F}$. ater density}

Figure 4 shows $\mathrm{Pb}$ in sediments in January 2017. Based on statistical test results, the correlation of $\mathrm{Pb}$ accumulated in $F$. ater with $F$. ater density in January was $r=0.665$. This value indicates a strong correlation between $\mathrm{Pb}$ content in sediment with $F$. ater density (criteria 0.60-0.799 has a strong correlation). The correlation of $\mathrm{Zn}$ accumulated in $F$. ater with $F$. ater density in November was $r=0.891$. This means that $\mathrm{Zn}$ in sediment greatly affects $F$. ater density (Figure 5). The correlation of $Z$ n content in sediments with $F$. ater density on December was $r=-0.838$. This number indicates a negative correlation, the correlation was very weak, meaning that $\mathrm{Zn}$ in the sediment does not affect the $F$. ater density (Figure 6). The correlation of $\mathrm{Zn}$ in $F$. ater with the density of $F$. ater in January was $r=-0.240$. this value also indicates a very weak correlation (Figure 7).

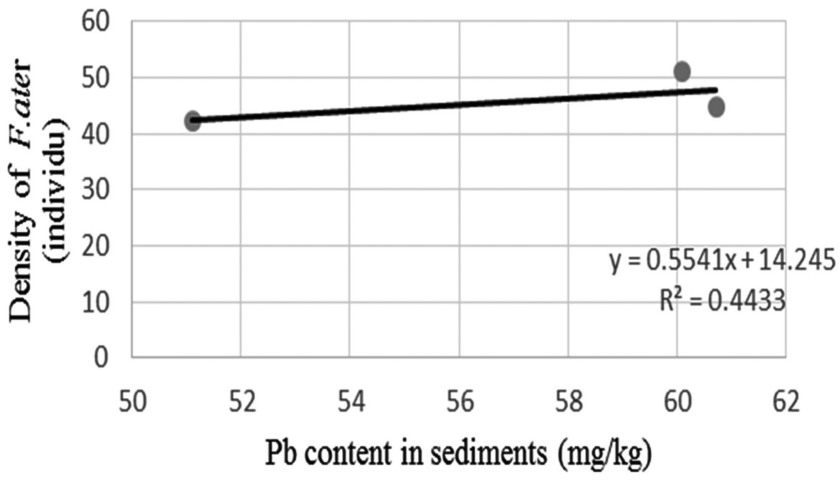

Figure 4 . Correlation $\mathrm{Pb}$ in Sediment with Density of $F$. ater on January 2017 
Proceedings of MICoMS 2017

\section{2}

Figure 5.

Correlation $\mathrm{Zn}$ in

Sediment with $F$. ater Density on November 2016

Figure 6.

Correlation $\mathrm{Zn}$ in

Sediment with

Density of $F$. ater on

December 2016

Figure 7.

Correlation $\mathrm{Zn}$ in

Sediment with $F$. ater Density on January 2017
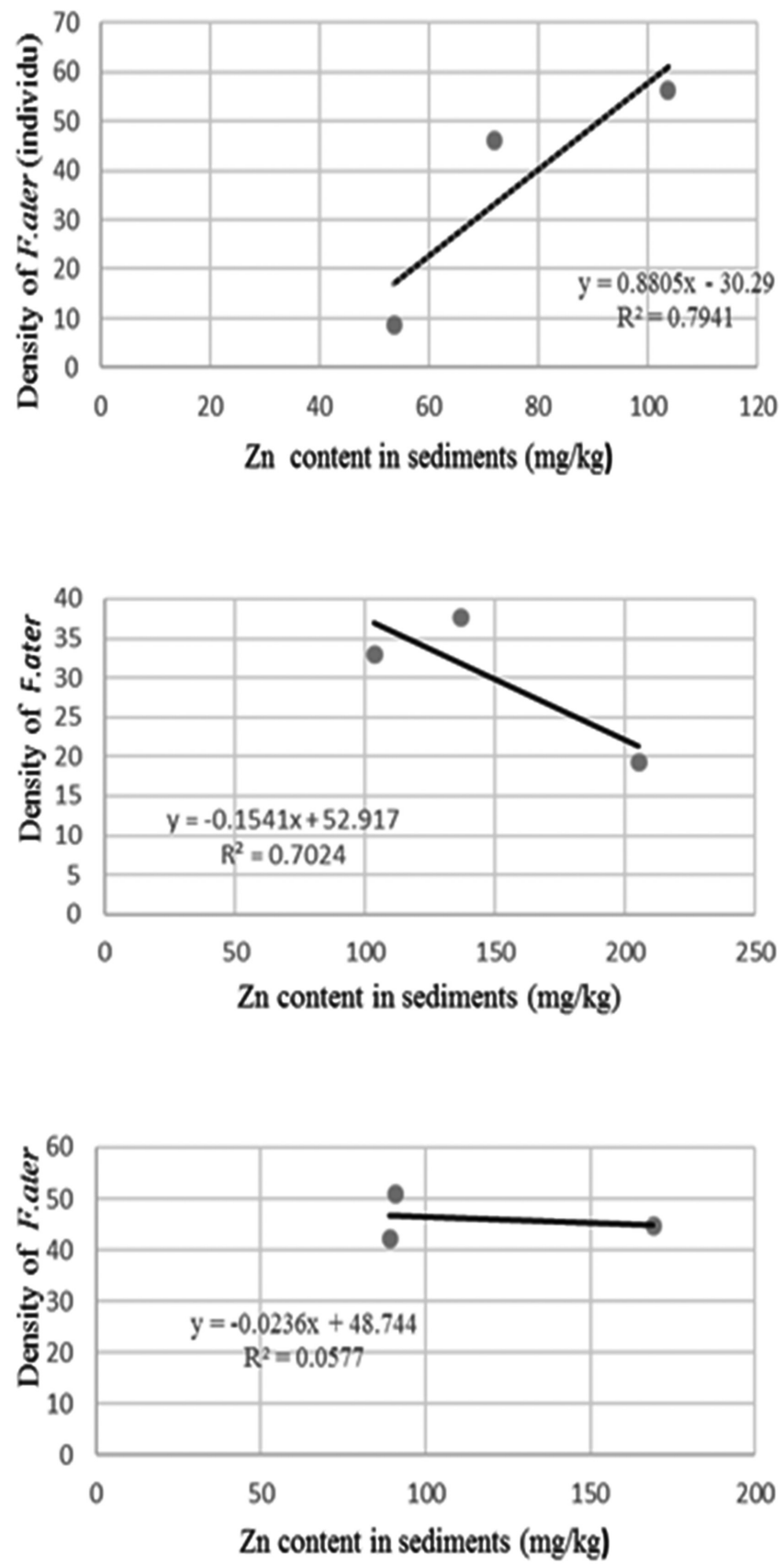


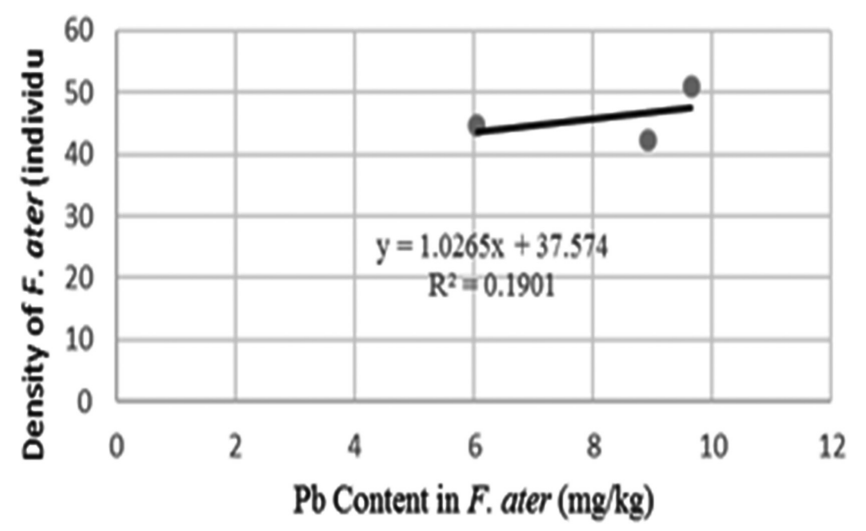

Correlation of Lead and Zinc

Contents in Sediments and Faunus Ater 493

Figure 8. Correlation $\mathrm{Pb}$ in $F$. ater with $F$. ater Density on January 2017

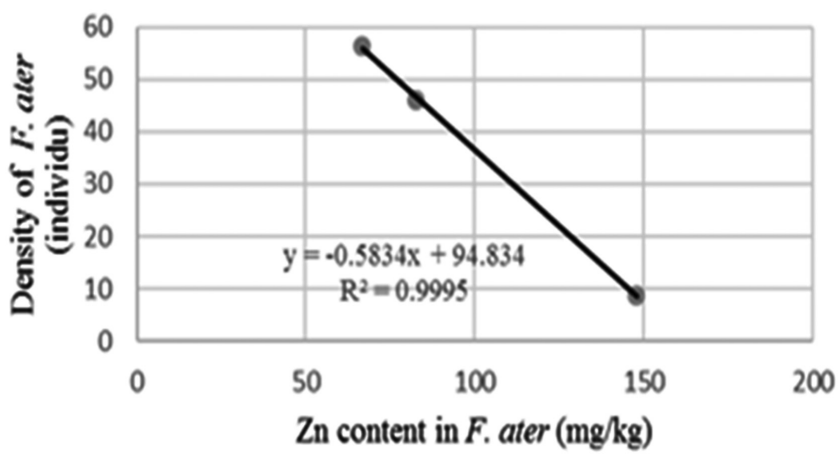

Figure 9. Correlation $\mathrm{Zn}$ in $F$. ater with $F$. ater Density on November 2016

The correlation test between $\mathrm{Pb}$ and $\mathrm{Zn}$ in sediment with $F$. ater density showed significant relationship in January (for $\mathrm{Pb}$ ) and November (for $\mathrm{Zn}$ ), while for December and January only $\mathrm{Zn}$ affected the $F$. ater density. Figs. 4 and 5 showed that $\mathrm{Pb}$ and $\mathrm{Zn}$ in sediment does not cause a population decline of $F$. ater, while Figs. 6 and 7 showed that $Z$ n content affects the $F$. ater population. This situation is caused by the habitat and conditions of the river at the time of sampling. F. ater if located in a favorable habitat, a muddy area, then the number of snails will be abundant because of abundant food (Niem et al., 1998). The condition of the stream also affects the amount of $\mathrm{Pb}$ and $\mathrm{Zn}$ in sediment and $F$. ater. Differences in type, age, and physiology of $F$. ater, also play a role in the physical and chemical properties.

\subsection{Correlation of $\mathrm{Pb}$ and $\mathrm{Zn}$ in $\mathrm{F}$. ater with density of $\mathrm{F}$. ater}

Correlation of $\mathrm{Pb}$ in $F$. ater with density of $F$. ater on January was $r=0.436$. This value indicates a positive correlation (criteria 0.40-0.599: middle correlation) which mean that $\mathrm{Pb}$ in $F$. ater affected the $F$. ater density (Figure 8). Correlation of $\mathrm{Zn}$ in $F$. ater with density of $F$. ater in November was $r=-0.999$. This value indicates that $Z n$ in $F$. ater does not affect its density (Figure 9). Correlation of $\mathrm{Zn}$ in $F$. ater with its density in December was 
Proceedings of $r=-0.860$, which means that, $\mathrm{Zn}$ concentration in $F$. ater does not affect the density level MICoMS 2017 (Figure 10). Correlation of $Z n$ in $F$. ater with its density in January was $r=-0.989$. This value indicates a very weak correlation (Figure 11).

494

\section{Conclusions}

(1) $\mathrm{Pb}$ and $\mathrm{Zn}$ in sediment showed a fluctuating relationship in each month of sampling with density of $F$. ater.

(2) The correlation of $\mathrm{Pb}$ in sediment with $F$. ater density showed a medium correlation in January 2017 with $r$-value $=0.665$.

(3) The relationship of $\mathrm{Zn}$ in sediment in November 2016 greatly affects $F$. ater density with $r$-value $=0.891$.

(4) The relationship of $\mathrm{Pb}$ accumulation in $F$. ater with $F$. ater density indicated a medium correlation in January 2017 with $r$-value $=0.436$.

Figure 10.

Correlation $\mathrm{Zn}$ in

F. ater with F. ater

Density on December

2016

Figure 11.

Correlation $\mathrm{Zn}$ in

F. ater with F. ater

Density on January

2017
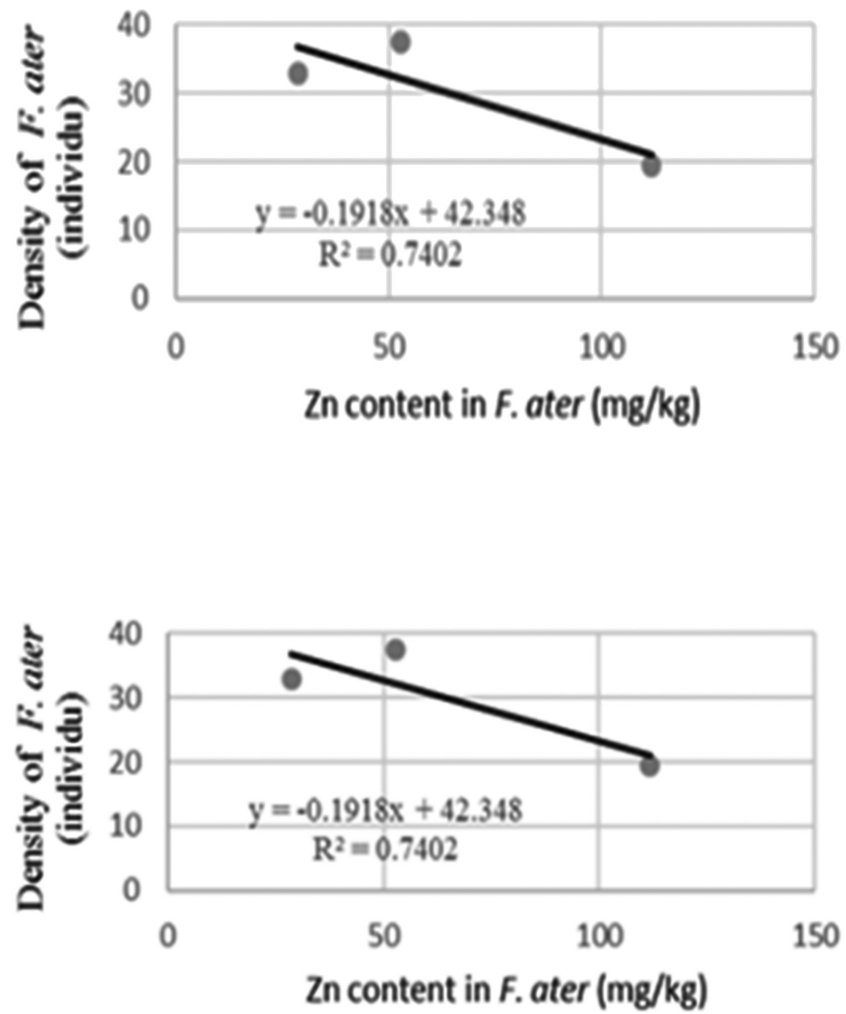


\section{References}

Correlation of

Abd El-Wakeil, K.F., Obuid-Allah, A.H., Mohamed, A.H., Abd El-Aziza, F.E.-Z.A. (2013). “Community Structure of Molluscans in River Nileand its Branches in Assiut Governorate, Egypt". Egyptian Journal of Aquatic Research, Vol. 39, pp. 193-198.

APHA. (2005). Standard Methods for the Examination of Water and Wastewater (21st ed.). American Public Health Association, Washington DC.

Barbosa, F.S., and Barbosa, C.S. (1994). "The Bioecology of Snail Vector for Schistosomiasis in Brazil". Cadernos de Sau'dePu'blica, Vol. 10, No. 2, pp. 200-209.

Lead and Zinc

Contents in

Sediments and Faunus Ater

495

Brower, J. E., danZar, J.H. 1989. Field and Laboratory Methods for General Ecology. W. M. Brown Company Publ. Dubuque Lowa.

Cañete, R., Yong, M., Sa’nchez, J., Wong, L. and Gutie'rrez, A. (2004). "Population Dynamics of Intermediate Snail Hosts of Fasciola hepatica and Some Environmental Factors in San Juan Martinez Municipality, Cuba”. Memo'rias do Instituto Oswaldo Cruz, Rio de Janeiro, Vol. 99, No. 3, pp. 257-262.

Karimi, G.R., Derakhshanfar, M. and Paykari, H. (2004). "Population Density, Trematodal Infection and ecology of Lymnaea Snails in Shadegan, Iran”. Archives of Razi Institute, Vol. 58, pp. 125-129.

Kastoro, W. (1988). "Beberapa Aspek Biologi Kerang Hijau (Perna viridis L) dari Perairan Binaria Ancol Teluk Jakarta”. Jurnal Penelitian Perikanan Laut, Vol. 45, pp. 21-32.

Kazibwe, F., Makanga, B., Rubaire-Akiiki, C., Ouma, J., Kariuki, C., Kabatereine, N.B., Booth, M., Vennervald, B.J., Sturrock, R.F. and Stothard, J.R. (2006). "Ecology of Biomphalaria (Gastropoda: Planorbidae) in Lake Albert, Western Uganda: Snail Distribution, Infection with Schistosomes and Temporal Associations with Environmental Dynamics”. Hydrobiologia, Vol. 568, pp. 433-444.

Kloos, H., de Souza, C., Gazzinelli, A., Filho, B.S.S., de Costa Temba, P., Bethony, J., Page, K., Grzywacz, C., Lewis, F., Minchella, D., Loverde, P. and Oliveira, R.C. (2001). "The Distribution of Biomphalaria spp. in Different Habitats in Relation to Physical, Biological, Water Contact and Cognitive Factors in a Rural Area in Minas Gerais, Brazil". Memo'rias do Instituto Oswaldo Cruz, Rio de Janeiro, Vol. 96, pp. 57-66.

Krebs, C.J. (1989). Ecology: The Experimental Analysis of Distribution and Abundance (3rd ed.). Harperand Row Publishers, New York.

Mageed, A.A.A. (2006). "Spatio-Temporal Variations of Zooplankton Community in the Hypersaline Lagoon Of Bardawil, North Sinai, Egypt”. Egyptian Journal of Aquatic Research, Vol. 32, No. 1, pp. 168-183.

Mostafa, O.M.S. (2009). "Effect of Salinity and Drought on the Survival of Biomphalariaarabica, the Intermediate Host of Schistosomamansoni in Saudi Arabia”. Egyptian Academic Journal of Biological Science, Vol. 1, No. 1, pp. 1-6.

Pratisto, A. (2004). Cara Mudah Mengatasi Statistik dan Rancangan Percobaan dengan SPSS 12, Yogyakarta Universitas Negeri, Yogyakarta.

Stell, T. (1989). Principles and Procedures of Statistics. McGraw-Hill, New York.

Suhendrayatna, O.A. and Gultom, A.C. (2011). "Mercury Levels and Distribution in Organs of Freshwater Organisms from Krueng Sabe River, Aceh Jaya. In Indonesia 6th Annual International Workshop \& Expo on Sumatra Tsunami Disaster \& Recovery 2011 in Conjunction with 4th South China Sea Tsunami Workshop T-417.

Svavarsson, J.A., Granmo, R., Ekelund, R. and Szpunar, J. (2001). “Occurrence and Effects of Organition on Adult Common Whelk Buccinum undatum (Molusca, Gastropods) in Harbours and in a Simulated Dredging Situation”. Marine Pollution Bulletin, Vol. 42, pp. 370-376.

US-EPA. (1989). "EPA Superfund Record of Decision Picatinny Arsenal (US Army) Rockaway". Township NJ US Environmental Protection Agency Superfund. Available: http://www.epa.gov/ superfund/sites/rods/fulltext/r0289093.pdf. 
Proceedings of Utzinger, J., Mayombana, C., Mez, K. and Tanner, M. (1997). "Evaluation of chemical and physical MICoMS 2017 morphological factors as potential determinants of Biomphalariapfefferi (Krauss, 1848) distribution". Memo'rias do Instituto Oswaldo Cruz, Rio de Janeiro, Vol. 92, No. 3, pp. 323-328.

\section{Corresponding author}

Rahmi Agustina can be contacted at ami.binti.asyar@gmail.com 